\title{
Rozi Souzanzan
}

English Language Instructor, PhD Candidate in TEFL

English Language Department, Shiraz Branch, Islamic Azad University, Shiraz, Iran

r.souzanzan@yahoo.com

\section{Mohammad Sadegh Bagheri}

Assistant professor, PhD in TEFL

English Language Department, Shiraz Branch, Islamic Azad University, Shiraz, Iran

bagheries@gmail.com

\section{HYBRID LEARNING: THE IMPACT OF INTERACTING THROUGH SKYPE ON IRANIAN LEARNERS' SPEAKING ABILITY}

\begin{abstract}
The present article aims to investigate the impact of interactions through Skype on Iranian EFL learners' speaking ability. To meet this end, forty elementary students who were studying English at the Kish Language Institute, Shiraz Branch, Iran participated in the study. Of this number, twenty eight were female and twelve were male students. Their age range was between twenty to thirty five and they were divided into two groups randomly. During the instruction which lasted for two and a half months, the participants of the experimental group interacted with the teacher on their courserelated topics for one hour per week according to a schedule besides their weekly four hour face-toface classes. The speaking paper of the Key English Test (KET) was administered as to assess the participants' speaking ability. The findings of the study indicated that the participants of the experimental group outperformed those of the control one. This outperformance can be accounted for by the Long's Interaction hypothesis (1996), Krashen's Input hypothesis (1977), and lower affective filters.
\end{abstract}

Keywords: Skype; Speaking Ability; Hybrid Learning; Iranian EFL Learners.

\section{INTRODUCTION}

For a lot of learners the primary purpose to learn a foreign language is to be able to speak it. This might be due to the fact that by being able to speak a foreign language, communicating with people of other countries, ethnic groups, races, etc. might be possible. Speaking a foreign language also enables individuals to build their confidence, self-esteem, comprehension, and more [1].

Being able to speak a foreign language is a hard and challenging task. To acquire speaking, one needs to gain a mastery over various language subsystems in such a way that they can be used spontaneously in real-life communications. Consequently, one of the key roles of language teachers is to provide language learners with as many opportunities as possible in order to help them develop their speaking skill, although it is a demanding task for many of EFL teachers.

In the past, teaching of speaking was only confined to traditional face-to-face instruction within formal classroom settings. Now a days, with the quick growth of Information and Communication Technologies (ICTs), it is obvious that Internet-based Technologies play a vital role in teaching/learning a foreign language. Therefore, a lot of language teachers have decided to integrate such emerging technologies into their daily lesson plans.

Taking the vast impact of ICTs on human interactions into account, one can easily conclude that communication between language teachers and students is not solely bounded to face-to-face classroom interactions any more. On the contrary, ICTs offer a wide range of options to language 
teachers and students to have online synchronous and asynchronous communication. One of the ICT tools which can contribute to language learning/teaching by its very nature is Skype.

Skype is a software application which makes use of voice over Internet protocol (VoIP) technology "that transforms voice signals into data streams which are transmitted over the Internet and converted back to audio by the receiver's computer" $[2,2]$. Its contribution to language learning/teaching is due to the fact that it allows "learners to interact, modify and elaborate their input (Doughty \& Long, 2003) as long as they are engaged in meaningful 'conversation' [3, 1949].

Skype makes synchronous and asynchronous communication possible. Skype users are enabled to have individual or in-group online chats or conferences by means of a webcam and a headset. This property provides the chance of communicating through Skype without the restrictions of time and space which in turn, converts Skype into a useful tool for language teaching and learning. As stated by Elia [4], Skype makes the exchange of language much easier by providing the opportunity for two people of different mother tongues to collaborate in order to learn the language of each other. It gives language learners the opportunity of starting language exchanges anytime they connect to the Internet. Through Skype, users can share files or screen shots as required. Furthermore, Skype users can still communicate with each other by leaving instant messages when webcams and headsets are not available. Furthermore, Skype can be utilized as a means for student-to-student teaching, remote classroom monitoring, tours and field trips, and bringing in guests to the classroom. Lee [5] considers the following as the potential advantages of Skype:

1. It does not need advanced hardware beyond a desk top or a laptop computer.

2. It is highly accessible as long as an Internet connection is available.

3. With the widespread use of technological devices, for their regular users, the knowledge and skills required to use Skype is not particularly new.

4. Skype promotes collaborative and authentic learning.

5. It enables synchronous and asynchronous communication among language teachers and learners.

6. Via Skype, class materials can be updated and adapted easily and quickly which is really beneficial to teachers who desire to tailor their lessons according to students' learning pace.

Considering the context where this study was conducted, the participants had almost restricted opportunities to have access to the target language outside the classroom, which is the norm because of Iran's EFL context. This reality did not contribute to Iranian EFL learners' speaking ability because their exposure to the target language was entirely limited to their English class.

The above-mentioned pros of Skype in general and learning a foreign language in particular stood for vital reasons and motivation to start this research with the main objective of finding out the impact of interactions through Skype on the speaking ability of Iranian EFL learners.

\section{LITERATURE REVIEW}

This part reviews some of the previously done research on the utilization of Skype in education and ELT.

Elia [4] conducted a study to explore the effect of Skype for language learning in Tandem. She used The Mixxer (http://www.language-exchanges.org/) that is a free educational website for 
language exchanges through Skype. She came to the conclusion that Skype language learning over "Mixxer" can be a convincing application to be widely supported and experimented. In addition, it was concluded that Skype might be an efficient tool and a valid aid to EFL learners who always encounter problems in having contact with native speakers.

Beltrán [6] conducted a study to explore the use of Skype chat for improving writing skills in an A2 adult learners group. She concluded that Skype text chat increased students' motivation through the use of technology and was an opportunity to enhance the teacher's performance.

Parker, Boase-Jelinek, and Herrington [7] led a qualitative study to investigate how synchronous group chat within Skype was used in a graduate level course for preservice teachers, how students responded to it, and to what extent it led to a development of community learning. It was found that few participants of this study used chat for addressing immediate problems and for facilitating group projects and the majority of them did not use chat at all for reasons that were not established in the study.

Chou [8] directed a pilot study in a college course to determine if Skype, along with other Web 2.0 technologies, could be used to support online collaborative learning. Chou determined that Facebook, Podcasting, Skype, Blogging, and Wikis improved students' learning in online discussions.

Strang [9] conducted a study on Skype in an online business mathematics course and found that students who participated in Skype-led discussions gained a statistically higher final grade than those in the control group.

Guo [10] found that the development of activities through a web conferencing tool creates real communicative needs for students to speak in the target language.

Macharaschwili and Coggin [11] used Skype in a group of doctoral students who met faceto-face in a classroom. Skype was integrated to connect students who were absent to the classroom discussions. The study focused on interactions and opportunities for scaffolding between the host student and the Skype student, between other students and the Skype student, and between the instructor and the Skype student. They found that Skype could be effectively used to connect distant learners to face-to-face classrooms.

Verjano conducted a small scale study in 2013 to examine the impact of using Skype in a primary class in Spain. The data from the investigation supported the argument that digital resources for foreign language learning hold great potential as mediating tools for increased motivation and enhanced peer interaction [12].

A pilot study was conducted on 42 students attending an English conversation course by Yen, Hou, and Chang [13]. Students' speaking errors during a role-playing Skype-based activity were being investigated with both quantitative and qualitative analysis. The findings of this pilot study indicated that Skype in conjugation with role-playing activities could gradually reduce the number of speaking errors and help improve speaking skills of EFL learner.

Romaña Correa [14] carried out a research project on the teaching and learning of English through the use of Skype conference calls. The research was conducted with a group of $12 \mathrm{EFL}$ adult learners in the language institute of Universidad Distrital Francisco José de Caldas, Bogotá, Colombia. The findings of this study suggest that Skype conference calls might be considered as an influential computer-mediated communication tool in order to promote EFL learners' speaking skill.

Taking the previous studies into account, it can be seen that a few of them addressed the probable effect of interacting through Skype on enhancing the speaking ability of elementary EFL learners which is the focus of the present article. 


\section{METHOD}

The method section deals with the participants of the study, the instrument used in the study, the procedure or the step by step explanation of phases followed in the study, and a brief explanation of the data collection and analysis.

\subsection{Participants}

The participants of this study were forty elementary students who were studying English at the Kish Language Institute, Shiraz Branch, Iran. They were placed into elementary-four level according to an interview placement test carried out on the basis of the course content. Total English elementary was their course book that was divided into four parts which were taught during four elementary levels. As a result, the participants were expected to master enough English to communicate in simple situations. Of this number, twenty eight were female and twelve were male students. Their age range was between twenty to thirty five.

\subsection{Instrument}

The instruments used for the study were two parallel Speaking papers of the Key English Test (KET) which were administered in the form of an interview, one as the pre-test and the other as the post-test. The KET is an examination at a pre-intermediate level. It reveals that one can communicate in simple situations and has gained a good foundation in learning English.

\subsection{Procedures, Data Collection, and Data Analysis}

First, the participants were divided into two groups randomly. Each group included twenty students. One of them was considered as the control and the other one as the experimental group. In order to see if the participants in both groups were at the same level of speaking ability, the speaking paper of the Key English Test (KET) was taken in the form of an interview. Each interview took about eight to ten minutes per pair of participants and contained two parts: In the first part, each participant interacted with the interviewer. The focus of this section was to tap into the language generally associated with meeting people for the first time, and giving factual personal information. In the second part, participants interacted with each other. The interviewer set up the activity by using a standardized rubric, and consequently participants asked and answered questions using prompt materials. The language focus of this section was to elicit nonpersonal factual information related to daily life. The interviewer awarded marks by applying performance descriptors from the analytical assessment scales for the following criteria: 1 . Grammar and vocabulary, 2. Pronunciation, 3. Interactive communication. The assessment scale is available in the Appendix.

To account for the consistency of pre-test speaking scores within an interviewer, all interviews were recorded, watched and marked again by the first interviewer within a week interval. Later, the intra-rater reliability between these pairs of scores was calculated. After that, a second trained interviewer was asked to watch the recorded videos and score them once more and finally, the correlation between the second interviewer's marks and the mean scores assigned by the first interviewer was calculated to estimate the inter-rater reliability between raters.

Being assured of the consistency of speaking marks within and among interviewers, a oneway ANOVA was run on the participants' speaking test scores. To gain more reliable results, the mean of the three speaking scores was calculated and used as the entry data. Due to the fact that 
there was no statistically significant difference in the performances of the students in these two groups, they were considered to be homogenous.

During the instruction, which continued for two and a half months, the participants of both control and experimental groups attended their routine face-to-face classes. However, their outof-class activities were different. The participants of the experimental group were each given a timetable to interact with the teacher through Skype on the topics related to their weekly lessons for one hour a week. The schedule had flexibility so that if a participant could not afford interacting with the teacher at the specified time, a substitute participant would compensate for that. Therefore, no time was wasted this way.

After the instruction, all participants in both groups took their speaking post-test. Once more the parallel version of the KET speaking paper was taken in the form of an interview. Like pre-test, all interviews were recorded and watched after one week by the first interviewer and marks were assigned to individual participants for the second time. Then, the intra-rater reliability between these pairs of scores was calculated. Next, a second trained interviewer was asked to watch the recorded videos and score them again and then, the correlation between the second interviewer's marks and the mean scores assigned by the first interviewer was calculated to estimate the inter-rater reliability between raters. Finally, a one-way ANOVA was run on the participants' post-test speaking scores. To gain more reliable results, the mean of the three speaking scores was calculated and used as the entry data.

\section{RESULTS}

For the purpose of examining the consistency of the pre-test speaking scores within the first interviewer, all the interviews were recorded and scored once more within a week interval by the first interviewer. Then, a Spearman Correlation was run to examine the degree of go-togetherness of these pairs of scores. The result is shown in Table 1.

Table 1

Intra-rater Correlation between the First Rater's Speaking Scores in the Pre-test

\begin{tabular}{rlrr}
\hline & & Rater A1 & Rater A2 \\
\hline \multirow{3}{*}{ Rater A1 } & Pearson Correlation & 1 & $.942^{* *}$ \\
& Sig. (2-tailed) & & .000 \\
& N & 40 & 40 \\
& Pearson Correlation & $.942^{* * *}$ & 1 \\
Rater A2 & Sig. (2-tailed) & .000 & \\
& N & 40 & 40 \\
\hline
\end{tabular}

As Table 1 indicates the correlation between the first rater's pairs of scores is .942 . Consequently, one can easily conclude that the degree of go-togetherness of the scores assigned by the first rater or their intra-rater reliability is high $(\mathrm{r}=0.9)$. In order to examine the consistency of the pre-test speaking scores among raters, a second trained and experienced rater was asked to watch the recorded interviews another time and then score them according to the same scale as the first rater did. For more accuracy, first the average of pairs of scores awarded by the first interviewer was calculated and then the results were used as the entry data to calculate the inter- 
rater reliability. Using Pearson Correlation Formula, the degree of go-togetherness or inter-rater reliability between the first and second rater's sets of scores was calculated and its result is shown in Table 2.

Table 2

\section{Inter-rater Correlation between the First and Second Raters' Speaking Scores in the Pre-test}

\begin{tabular}{rlrr}
\hline & & Rater A1+2 & Rater B \\
\hline \multirow{3}{*}{ Rater A1+2 } & Pearson Correlation & 1 & $.946^{* *}$ \\
& Sig. (2-tailed) & & .000 \\
& $\mathrm{~N}$ & 40 & 40 \\
\multirow{5}{*}{ Rater B } & Pearson Correlation & $.946^{* * *}$ & 1 \\
& Sig. (2-tailed) & .000 & \\
& $\mathrm{~N}$ & 40 & 40 \\
\hline
\end{tabular}

As Table 2 illustrates the correlation between the first and second raters' scores is .946 . This fact indicates that there is a remarkably high index of reliability between the scores assigned by the first and second raters. In other words, the inter-rater reliability is high $(r=.9)$. Finally, the mean of the three pre-test speaking scores was calculated and considered as the raw scores for further computations.

To examine the homogeneity of the participants in the control and experimental groups in terms of their speaking ability before the instruction, a one-way ANOVA was run on their speaking pre-test scores. See Table 3 for its results.

Table 3

\section{One-Way ANOVA for the Homogeneity of Participants in the Control and Experimental Groups}

\begin{tabular}{lrrrrr}
\hline & Sum of Squares & df & Mean Square & F & \multicolumn{1}{c}{ Sig. } \\
\hline Between Groups & .225 & 4 & .225 & .042 & .839 \\
Within Groups & 203.775 & 38 & 5.363 & & \\
Total & 204.000 & 39 & & & \\
\hline
\end{tabular}

As Table 3 indicates, the significance level is .839 for speaking which is higher than 05 . As a result, it could be inferred that there was not a statistically significant difference among groups in terms of their speaking ability. In other words, all the participants in all groups were at the same level of speaking ability before the instruction.

After the instruction, all participants in the control and experimental groups took another speaking test. Like the pre-test, all the interviews were recorded. And the same procedures were followed to calculate the intra-rater and inter-rater reliabilities as presented in Tables 4 and 5 respectively. 
Table 4

Intra-rater Correlation between the First Rater's Speaking Scores in the Post-test

\begin{tabular}{rlrr}
\hline & & Rater A1 & Rater A2 \\
\hline \multirow{3}{*}{ Rater A1 } & Pearson Correlation & 1 & $.973^{* * *}$ \\
& Sig. (2-tailed) & & .000 \\
& N & 40 & 40 \\
& Pearson Correlation & $.973^{* *}$ & 1 \\
\multirow{2}{*}{ Rater A2 } & Sig. (2-tailed) & .000 & 40 \\
& N & 40 & 4 \\
\hline
\end{tabular}

According to Table 4, the Spearman Correlation is .973. Thus, it could be deduced that the intra-rater reliability between the pairs of speaking scores assigned by the first rater was high $(\mathrm{r}=.9)$.

Table 5

Inter-rater Correlation between the First and Second Raters' Speaking Scores in the Post-test

\begin{tabular}{|c|c|c|c|}
\hline & & Rater A1+2 & Rater B \\
\hline \multirow{3}{*}{ Rater A1+2 } & Pearson Correlation & 1 & $.993^{* *}$ \\
\hline & Sig. (2-tailed) & & .000 \\
\hline & $\mathrm{N}$ & 40 & 40 \\
\hline \multirow{3}{*}{ Rater B } & Pearson Correlation & $.993^{* *}$ & 1 \\
\hline & Sig. (2-tailed) & .000 & \\
\hline & $\mathrm{N}$ & 40 & 40 \\
\hline
\end{tabular}

According to Table 5, the Spearman Correlation is .993. So, it could be concluded that the inter-rater reliability between the scores assigned by the first and second rater was high $(r=.9)$.

Being confident of the intra- and inter-rater reliabilities of scores, all participants' gain scores were calculated by subtracting their pre-test scores from their post-test scores. In order to discover whether the speaking gain scores for these two groups showed any significant differences or not, a one-way ANOVA was run on the gain scores. The results are shown in Table 6.

Table 6

One-Way ANOVA to Compare the Participants' Speaking Gain Scores in the Control and Experimental Groups

\begin{tabular}{|c|c|c|c|c|c|}
\hline & Sum of Squares & $\overline{d f}$ & Mean Square & $\mathrm{F}$ & Sig. \\
\hline Between Groups & 105.625 & 1 & 105.625 & 22.932 & .000 \\
\hline Within Groups & 175.025 & 38 & 4.606 & & \\
\hline Total & 280.650 & 39 & & & \\
\hline
\end{tabular}


As Table 6 indicates, the significance level $(\mathrm{P}=.000)$ is lower than .05 . Consequently, it could be concluded that there was a significant difference in the participants' speaking gain scores in the control and experimental groups. Therefore, it can be inferred that interacting through Skype can be an effective factor in enhancing Iranian EFL learners' speaking ability.

\section{DISCUSSION}

The purpose of the present study was to find out whether interacting through Skype could have an impact on Iranian EFL learners' speaking ability or not. The comparison of the learners' speaking gain scores in the control and experimental groups by means of a one-way ANOVA revealed a significant difference in favor of the experimental group as it is shown in Table 4.6. This outperformance might be due to the fact that interacting through Skype made students feel as if they were having face-to-face classes with the added comfort and ease which resulted from having classes in their own homes. This lower affective filter made the Skype learning experience fun and relaxing which allowed students to forget about their insecurities and inhibitions and speak more openly and freely. Besides, according to the Long's Interaction hypothesis (1996), their language proficiency and particularly their speaking ability promoted through having online interaction and communication with the teacher because they could interact, modify and elaborate their input while they were engaged in authentic conversations with the teacher. Moreover, considering the Krashen's input hypothesis (1977) which states that comprehensible input is important for language learning and that the effectiveness of comprehensible input is greatly increased when learners have to negotiate for meaning, it could be concluded that since the learners were more exposed to comprehensible input by means of communicating and negotiating meaning with a more advanced interlocutor as their teacher, their speaking ability improved. Besides, because Skype by its very nature involved both visual and auditory learners, it could have been really effective.

In addition, regarding the positive effects of Skype on the improvement of language learners' speaking ability, the obtained result of the present research is supported by a number of previously conducted studies. For instance, Yen's study [13] which indicated that Skype along with role-playing activities could gradually decrease the number of speaking errors and assist to enhance speaking skills of EFL learners is in line with the obtained result of the present study. Moreover, Guo's study [10] which indicated that the development of activities through a web conferencing tool created real communicative needs for students to speak in the target language is in agreement with the present study's result. Furthermore, Chou's pilot study [8] which revealed that Skype and other Web 2.0 technologies improved students' learning in online discussions supports the gained result of this study.

\section{PEDAGOGICAL IMPLICATIONS}

The result of the present study can support the positive impact of technology on improving the students' speaking ability. As a result, the course instruction can be designed in such a way that ICT tools have to be involved and required for the students' better learning the language. It necessitates the teachers' attempt to first empower themselves with a good knowledge of ICT tools, and then help their students to be technology-savvy through explaining the pros of blended learning for their language development so that they engage themselves in the process of learning 
a new language by using technology as a complementary factor and enjoy the merits of learning autonomously.

Furthermore, the result of the present study might help the material developers and syllabus designers to integrate technology into language programs. In other words, teachers can be required to use ICT tools as complementary or supplementary materials at home or in the classroom.

Implications for teachers: Providing teachers with more information about the concept of blended-learning brings about the best use of both physical and virtual environments by them to improve the quality of their students' learning. Additionally, by integrating ICT tools into traditional face-to-face instruction, teachers and students alike can update their own knowledge of technology.

Implications for syllabus designers: considering the positive role of ICT tools in improving the speaking ability of learners, course designers and material developers can take advantage of integrating ICT tools in language classes by means of adding some follow-up, out-of-class, technology-based activities for each lesson in the students' textbooks.

\section{REFERENCES}

1. Grauberg, W. (1997). The elements of foreign language teaching. Clevedon, UK: Multilingual Matters.

2. Educause. (December, 2007). 7 things you should know about Skype. Educause Learning Initiative, 1-2. Retrieved March 14, 2013, from http://net.educause.edu/ir/library/pdf/eli7032.pdf

3. Long, M. H., \& Doughty, C. J. (2009). The handbook of language teaching. Chichester, UK: WileyBlackwell. http://dx.doi.org/10.1002/9781444315783.

4. Elia, A. 2006. Language learning in tandem via Skype ${ }^{\mathrm{Tм}}$. CALL Technologies and the Digital Learner, 6 (3), 269-280.

5. Lee, S. (2013). A case study on the effects of an L2 writing instructional model for blended learning in higher education, The Turkish Online Journal of Educational Technology, 12 (4), 1-10.

6. Beltrán, O. C. (2009). The use of Skype ${ }^{\mathrm{TM}}$ chat for improving writing skills in an A2 adult learners group. Unpublished M.A. thesis in English Language Teaching -Autonomous Learning Environments, Universidad de la Sabana, Chía, Colombia.

7. Parker, J., Boase-Jelinek, D., \& Herrington, J. (2011). Perceptions and reflections: Using Skype chat to build a community of learners. Murdoch. Retrieved from: researchrepository.murdoch.edu. Google Scholar

8. Chou, P. N. (2012). Teaching strategies in online discussion board: A framework in higher education. Higher Education Studies, 2(2). doi:10.5539/hes.v2n2p25.

9. Strang, K. D. (2012). Skype synchronous interaction effectiveness in a quantitative management science course. Decision Sciences Journal of Innovative Education, 10 (1), 3-23.

10. Guo, S. (2013). Applying web-conferencing in a beginners' Chinese class. 30th ASCILITE Conference 2013 Proceedings. Macquire University, Sydney, Australia.

11. Macharaschwili, C. E. \& Coggin, L. S. (2013). A Skype-buddy model for blended learning. Journal of Interactive Learning Research, 24(2), 167-190.

12. Verjano, A. C. (2013). Using Skype in a primary class: A case study, Bellaterra Journal of Teaching \& Language Learning \& Literature, 6 (2), 49-68.

13. Yen, Y. C., Hou, H. T., \& Chang, K. E. (2013). Applying Skype in English as a foreign language instruction: Effect on students' speaking errors. Lecture Notes in Computer Science (including subseries Lecture Notes in Artificial Intelligence and Lecture Notes in Bioinformatics), 8167 LNCS, 312-319. DOI: 10.1007/978-3-64241175-5_32

14. Romaña Correa, Y. (2015). Skype ${ }^{\text {TM }}$ conference calls: A way to promote speaking skills in the teaching and learning of English, PROFILE Issues in Teachers' Professional Development, 17 (1). 143-156. 


\section{APPENDIX}

\section{KET Speaking Assessment Scale}

\begin{tabular}{|c|c|c|c|}
\hline$A 2$ & Grammar and Vocabulary & Pronunciation & Interactive Communication \\
\hline 5 & $\begin{array}{l}\text { Shows a good degree of control of simple } \\
\text { grammatical forms. } \\
\text { Uses a range of appropriate vocabulary } \\
\text { when talking about everyday situations. }\end{array}$ & $\begin{array}{l}\text { Is mostly intelligible, and has some control } \\
\text { of phonological features at both utterance } \\
\text { and word levels. }\end{array}$ & $\begin{array}{l}\text { Maintains simple exchanges. } \\
\text { Requires very little prompting and support. }\end{array}$ \\
\hline 4 & \multicolumn{3}{|c|}{ Performance shares features of Bands 3 and 5 . } \\
\hline 3 & $\begin{array}{l}\text { Shows sufficient control of simple } \\
\text { grammatical forms. } \\
\text { Uses appropriate vocabulary to talk about } \\
\text { everyday situations. }\end{array}$ & $\begin{array}{l}\text { Is mostly intelligible, despite limited control } \\
\text { of phonological features. }\end{array}$ & $\begin{array}{l}\text { Maintains simple exchanges, despite some } \\
\text { difficulty. } \\
\text { Requires prompting and support. }\end{array}$ \\
\hline 2 & \multicolumn{3}{|c|}{ Performance shares features of Bands 1 and 3.} \\
\hline 1 & $\begin{array}{l}\text { Shows only limited control of a few } \\
\text { grammatical forms. } \\
\text { Uses a vocabulary of isolated words and } \\
\text { phrases. }\end{array}$ & $\begin{array}{l}\text { Has very limited control of phonological } \\
\text { features and is often unintelligible. }\end{array}$ & $\begin{array}{l}\text { Has considerable difficulty maintaining } \\
\text { simple exchanges. } \\
\text { Requires additional prompting and support. }\end{array}$ \\
\hline 0 & \multicolumn{3}{|c|}{ Performance below Band 1.} \\
\hline
\end{tabular}

\begin{tabular}{ll}
\hline A2 & \multicolumn{1}{c}{ Global Achievement } \\
\hline $\mathbf{5}$ & $\begin{array}{l}\text { Handles communication in everyday situations, despite hesitation. } \\
\text { Constructs longer utterances but is not able to use complex language except } \\
\text { in well-rehearsed utterances. }\end{array}$ \\
\hline $\mathbf{4}$ & \multicolumn{1}{c}{ Performance shares features of Bands 3 and 5. } \\
\hline $\mathbf{3}$ & $\begin{array}{l}\text { Conveys basic meaning in very familiar everyday situations. } \\
\text { Produces utterances which tend to be very short - words or phrases - with } \\
\text { frequent hesitation and pauses. }\end{array}$ \\
\hline $\mathbf{2}$ & $\quad$ Performance shares features of Bands land 3. \\
\hline $\mathbf{1}$ & $\begin{array}{l}\text { Has difficulty conveying basic meaning even in very familiar everyday } \\
\text { situations. } \\
\text { Responses are limited to short phrases or isolated words with frequent } \\
\text { hesitation and pauses. }\end{array}$ \\
\hline $\mathbf{0}$ & $\quad$ Performance below Band 1. \\
\hline
\end{tabular}




\title{
ГІБРИДНЕ НАВЧАННЯ: ВПЛИВ ВЗАСМОДІЇ ЧЕРЕЗ SКҮРЕ НА МОВЛЕННЕВІ ВМІННЯ ІРАНСЬКИХ СТУДЕНТІВ
}

\section{Розі Сузанзан}

викладач англійської мови, аспірант з TEFL

кафедра англійської мови, філія Шираз, Ісламський університет Азад, Шираз, Іран

r.souzanzan@yahoo.com

\section{Мохаммад Садег Багері}

доцент, PhD $з$ TEFL

кафедра англійської мови, філія Шираз, Ісламський університет Азад, Шираз, Іран

bagheries@gmail.com

\begin{abstract}
Анотація. Мета статті - дослідити вплив взаємодій через Skype на мовленнєві вміння іранських EFL студентів. Для дослідження було обрано сорок студентів початкового рівня, які вивчають англійську мову в Інституті іноземних мов Кіш, відділення Шираз, за участю Ірану у проведені досліджень. Серед обраних студентів: двадцять вісім - жінки і дванадцять - студенти чоловічої статі. Їх віковий діапазон становив від двадцяти до тридцяти п'яти років, і вони були розділені на дві групи випадково. Під час навчання, яке тривало протягом двох 3 половиною місяців, учасники експериментальної групи взаємодіяли з викладачем з їхніх тем, які пов'язані з основним навчальним курсом, протягом однієї години на тиждень відповідно до розкладу, крім своїх щотижневих чотирьох годин очних уроків. Для оцінювання рівня мовленнєвих умінь студентів був використаний Key English Test (KET). Результати дослідження показали, що учасники експериментальної групи перевершили студентів 3 контрольної групи. Така випереджальна динаміка може бути пояснена гіпотезою взаємодії Лонга (1996), гіпотезою вхідного матеріалу Крашена (1977), і нижчими афективними фільтрами.
\end{abstract}

Ключові слова: Skype; мовленнєві вміння; гібридне навчання; іранські студенти EFL.

\section{ГИБРИДНОЕ ОБУЧЕНИЕ: ВЛИЯНИЕ ВЗАИМОДЕЙСТВИЯ ЧЕРЕЗ SКУРЕ НА РЕЧЕВЫЕ УМЕНИЯ ИРАНСКИХ СТУДЕНТОВ}

\section{Рози Сузанзан}

преподаватель английского языка, аспирант TEFL

кафедра английского языка, филиал Шираз, Исламский университет Азад, Шираз, Иран

r.souzanzan@yahoo.com

\section{Мохаммад Садег Багери}

доцент, $\mathrm{PhD}$ в TEFL

кафедра английского языка, филиал Шираз, Исламский университет Азад, Шираз, Иран

bagheries@gmail.com

\begin{abstract}
Аннотация. Цель статьи - исследовать влияние взаимодействий через Skype на речевые умения иранских EFL студентов. Для исследования были выбраны сорок студентов начального уровня, изучающих английский язык в Институте иностранных языков Киш, отделение Шираз, с участием Ирана в исследовании. Из числа избранных студентов: двадцать восемь - женщины и двенадцать студенты мужского пола. Их возрастной диапазон составлял от двадцати до тридцати пяти лет, и они были разделены на две группы случайным образом. Во время обучения, которое длилось в течение двух с половиной месяцев, участники экспериментальной группы взаимодействовали с преподавателем по их темам, которые соответствовали основному курсу обучения, в течение одного часа в неделю согласно расписанию, кроме своих еженедельных четырех часов очных уроков. Для оценки уровня речевых умений студентов был использован Key English Test (KET). Результаты исследования показали, что участники экспериментальной группы превзошли студентов из контрольной группы. Такая опережающая динамика может быть объяснена гипотезой взаимодействия Лонга (1996), гипотезой исходного материала Крашена (1977), и более низкими аффективными фильтрами.
\end{abstract}

Ключевые слова: Skype; речевые умения; гибридное обучения; иранские студенты EFL.

\section{(c) $)$ BY-NC-SA}

This work is licensed under Creative Commons Attribution-NonCommercial-ShareAlike 4.0 International License. 